\title{
PELATIHAN PEMBUATAN SABUN CAIR UNTUK PENCEGAHAN PENULARAN COVID-19 DI KELURAHAN TIGA BALATA
}

\author{
Apriani Sijabat ${ }^{1 *}$, Osco P. Sijabat ${ }^{2}$ \\ 1,2 Universitas HKBP Nommensen Pematangsiantar \\ *Penulis Koresponsensi, email: aprianisijabat@gmail.com
}

Received:25/01/2021

Revised:13/02/2021

Accepted:15/02/2021

\begin{abstract}
The Covid-19 pandemic is still sweeping the entire world, therefore understanding and information is needed regarding the prevention of covid-19 transmission. One of them is by washing your hands using running water and soap. The purpose of this activity is to provide socialization to the community in the Tiga Balata village to prevent the spread of Covid-19. Activities carried out by providing training in making liquid hand washing soap. It is hoped that from this activity the people of Tiga Balata Village will become an example to socialize ways to prevent the spread of Covid-19 to the surrounding community. This activity is also expected to be able to create business opportunities for the community in the midst of the Covid-19 pandemic. The method used in this service is the method of counseling and training. This hand washing soap-making training aims to improve community skills, especially participants in activities amid the Covid-19 pandemic. The result of this service is that the community is enthusiastic about participating in the training and has produced liquid soap products for personal use and commercial use as business opportunities.
\end{abstract}

Keywords: handsoap, covid-19, training.

\begin{abstract}
Abstrak. Pandemi Covid-19 sampai saat ini masih melanda seluruh dunia, maka dari itu diperlukan pemahaman dan informasi mengenai pencegahan penularan covid-19. Salah satunya yaitu dengan mencuci tangan menggunakan air mengalir dan sabun. Tujuan kegiatan ini yaitu memberikan sosialisasi kepada masyarakat di kelurahan Tiga Balata untuk mencegah penyebaran Covid-19. Kegiatan dilakukan dengan memberikan pelatihan pembuatan sabun cuci tangan cair. Diharapkan dari kegiatan ini masyarakat kelurahan Tiga Balata menjadi contoh untuk mensosialisasikan cara pencegahan penyebaran Covid-19 ke masyarakat sekitar. Kegiatan ini juga diharapkan mampu menciptakan peluang usaha bagi masyarakat di tengah pandemi covid-19. Metode yang dilakukan dalam pengabdian ini adalah metode penyuluhan dan pelatihan. Pelatihan pembuatan sabun cuci tangan ini bertujuan untuk meningkatkan keterampilan masyarakat khususnya peserta kegiatan ditengah pandemi Covid19. Hasil pengabdian ini adalah masyarakat antusias dalam mengikuti pelatihan dan telah menghasilkan produk sabun cair untuk dapat digunakan pribadi maupun dikomersilkan sebagai peluang usaha.
\end{abstract}

Kata Kunci: Sabun cuci tangan, Covid-19, Pelatihan.

How to Cite: Sijabat, A., \& Sijabat, O. P. (2021). PELATIHAN PEMBUAT AN SABUN CAIR UNTUK PENCEGAHAN PENULARAN COVID-19 DI KELURAHAN TIGA BALATA. Mitra Mahajana: Jurnal Pengabdian Masyarakat, 2(1).

https://doi.org/10.37478/mahajana.v2i1.807

\section{PENDAHULUAN}

COVID-19 adalah penyakit yang disebabkan oleh virus SARS-CoV-2 yang merupakan bagian dari tipe virus Corona.Virus ini bisa menular jika kita kontak langsung dengan orang yang terinfeksi atau dengan cairan yang dikeluarkannya oleh saat batuk dan bersin.Virus dapat berpindah ke tubuh kita, bila tanpa sengaja kita menyentuh benda-benda tersebut lalu menyentuh wajah (mata, mulut, dan hidung) dengan tangan yang telah terkontaminasi. Sejauh ini kita sering mendengar anjuran untuk selalu mencuci tangan. Mencuci tangan disini bukan hanya sekedar membilas tangan dengan air saja tetapi harus menggunakan sabun dengan durasi waktu minimal 20 detik(Depkes 2009). Mengapa cuci tangan disarankan harus pakai sabun? Untuk menjawab pertanyaan tersebut kita harus tau terlebih dahulu bahwa semua jenis virus termasuk COVID-19 dapat aktif di luar tubuh manusia selama berjam-jam, bahkan berhari-hari. Mereka bisa menyebar melalui droplets, seperti saat bersin, batuk, atau saat pengidapnya berbicara. Desinfektan, cairan hand sanitizer, tisu basah, gel, dan krim yang mengandung alkohol semuanya berguna untuk membunuh virus ini, tetapi tidak seefektif 
sabun. Ketika kita beraktivitas sehari-hari, akan sulit bagi tangan untuk menghindari virus, bakteri, atau kuman dikarenakan mata tidak mampu melihat virusnya langsung karena bentuknya yang sangat kecil, sehingga mencuci tangan adalah langkah terbaik untuk menghindari tertular penyakit.

Banyak orang beranggapan bahwa mencuci tangan asal kena air saja sudah cukup ternyata para ahli mengatakan bahwa kita harus menggunakan sabun untuk membunuh virus yang menempel di tangan kita tidak cukup hanya membasuhnya saja. Melansir World Economic Forum, Palli Thordarson profesor di School of Chemistry di University of New South Wales menjelaskan bahwa virus cenderung terdiri dari tiga hal yakni genom asam nukleat (bahan genetiknya: DNA atau RNA), protein yang membungkus asam nukleat dan membantu replikasi virus di dalam tubuh inang, dan lapisan luar yang berlemak. Koneksi antara ketiga bagian komponen ini membentuk struktur virus, tetapi koneksi itu lemah karena tidak ada ikatan kovalen yang memberikan struktur yang lebih stabil. Sebaliknya, kata Thordarson, perakitan virus didasarkan pada interaksi "non-kovalen" yang lemah antara protein, RNA dan lipid. Mereka bersama-sama bertindak bersama seperti perekat sehingga sulit untuk memecah partikel virus yang terbentuk sendiri. Namun, sangat mungkin untuk memecah partikel dengan sabun, yang baik dalam melarutkan lapisan lipid yang mengelilingi virus. Ini juga menghancurkan semua ikatan lemah lainnya di dalam virus. Setelah itu terjadi, virus secara efektif akan hancur berantakan.

Mencuci dengan air saja jauh lebih kecil kemungkinannya untuk memindahkan virus dari permukaan kulit. Kita harus mencuci tangan dengan sabun karena sabun mengandung senyawa seperti lemak yang disebut amphiphiles, yang mirip dengan lipid yang ditemukan dalam membran virus. Ketika sabun bersentuhan dengan zat berlemak ini, sabun mengikatnya dan menyebabkannya terlepas dari virus. Ini juga yang memaksa virus melepaskan diri dari kulit. Mengenai jenis sabun apa yang harus dipakai juga bukan merupakan hal yang penting. Ini karena COVID-19 adalah virus, jadi sabun anti bakteri tidak memberi keunggulan tambahan dibandingkan jenis sabun yang lain. Kandungan bahan untuk pembuatan sabun pada pengabdian ini digunakan sodium lauril sulfat (SLS), texapon, $\mathrm{NaCl}$, pewarna, dan pewangi aroma melon. Sabun terbuat dari senyawa alkali( natrium hidroksida atau kalium hidroksida) yang dicampur dengan lemak nabati atau hewani serta pewangi(WHO,2009). Formulasi ini bersifat basa dan berfungsi membersihkan minyak dan kotoran di permukaan kulit yang cenderung bersifat sedikit asam. Berdasarkan informasi di atas maka tujuan dari PKM ini adalah untuk melatih masyarakat membuat sabun cair yang akan digunakan dalam kehidupan sehari - hari guna mencegah penularan virus covid-19.

\section{METODE PELAKSANAAN}

Dalam teknis pelaksanaan, tim pengabdian masyarakat akan mendata kembali anggota kelompok yang akan mengikuti pembimbingan dan pendampingan program pengabdian pada masyarakat ini. Metode pelaksanaan dan pendekatan yang akan dikembangkan dalam kegiatan program PKM ini dapat mengatasi pola pikir tentang pentingnya cuci tangan. Kegiatan PKM ini dilaksanakan pada bulan November-Desember 2020. Metode pelaksanaan program PKM ini meliputi dua hal yaitu sebagai berikut:

1. Metode Penyuluhan.

Metode penyuluhan merupakan salah satu metode yang akan dikembangkan dalam program PKM. Metode penyuluhan ini sangat penting pada anggota kelompok mitra untuk menambah pengetahuan sehingga terjadi perubahan kognitif. Artinya pola pikir yang dirubah terlebih dahulu untuk memudahkan proses kegiatan PKM selajutnya. 


\section{Metode Pelatihan}

Metode pelatihan dilakukan dengan langsung memberi contoh pembuatan sabun cair di kelurahan masyarakat Balata dan melatih para peserta pengabdian untuk membuat sabun cair yang akan digunakan untuk mencuci tangan.

Adapun bahan yang digunakan untuk pembuatan sabun cair ini antara lain sodium lauril sulfat (SLS), texapon, $\mathrm{NaCl}$, pewarna, dan penwangi aroma melon. Pembuatan sabun cair dengan tahapan dan takaran yang benar akan menghasilkan sabun cair yang berkualitas. Tahapan-tahapannya adalah sebagai berikut:

1. Mempersiapkan air bersih sebanyak 18 liter,

2. Melarutkan $1 \mathrm{~kg}$ SLS ke dalam air sambil diaduk terus hingga larut sempurna,

3. Menambahkan $1 \mathrm{~kg}$ Texapon ke dalam larutan pada langkah sebelumnya sambil diaduk terus hingga larut sempurna,

4. Menambahkan $1 \mathrm{~kg} \mathrm{NaCl}$ ke dalam larutan pada langkah sebelumnya sambil diaduk terus hingga larut sempurna,

5. Mengaduk larutan tersebut hingga mengental sempurna,

6. Menambahkan pewarna ke dalam larutan tersebut sambil diaduk hingga seluruh warna menyatu dengan sabun cair tersebut,

7. Menambahkan pewangi dalam hal ini tim pengabdi memilih aroma melon sambil diaduk terus hingga pewangi tersebut larut merata ke seluruh bagian,

8. Hasil pencampuran yang telah diaduk merata didiaamkan satu malam untuk mendapatkan kulaitas yang lebih baik,

9. Sabun cair yang telah didiamkan dapat digunakan dan dituang ke kemasan botol yang telah disediakan.

10. Sabun cair yang telah dikemas dapat digunakan maupun dikemas untuk dipasarkan.

\section{HASIL DAN PEMBAHASAN}

Pengetahuan seseorang tentang mencuci tangan menggunakan sabun dapat menghilangkan sejumlah besar virus dan bakteri yang menjadi penyebab berbagai penyakit, terutama penyakit yang menyerang saluran pencernaan seperti diare dan saluran nafas seperti influenza(Curtis, 2003). Hampir semua orang mengerti pentingnya mencuci tangan pakai sabun, namun masih banyak yang tidak membiasakan diri untuk melakukannya dengan benar pada saat yang penting. Mengapa kita harus cuci tangan dengan benar menggunakan sabun? Menurut WHO kita harus mencuci tangan dengan sabun karena mencuci tangan asal-asalan dengan air saja tidak dapat membunuh kuman pada tangan. Banyak penyakit yang dapat dicegah dengan mencuci tangan seperti penyakit cacingan, diare, infeksi saluran napas, TBC, Sakit perut, muntaber, radang tenggorokan, amandel, asma, gangguan pernapasan, flu, hingga penyakit yang mematikan seperti SARS, flu burung, flu babi.

Agar efektif, WHO (2009) telah menetapkan langkah-langkah cuci tangan pakai sabun sebagai berikut: membasahi kedua tangan dengan air mengalir, beri sabun secukupnya, menggosokan kedua telapak tangan dan punggung tangan, menggosok sela-sela jari kedua tangan, menggosok kedua telapak dengan jari-jari rapat, jari-jari tangan dirapatkan sambil digosok ke telapak tangan, tangan kiri ke kanan, dan sebaliknya, menggosok ibu jari secara berputar dalam genggaman tangan kanan, dan sebaliknya, menggosokkan kuku jari kanan memutar ke telapak tangan kiri, dan sebaliknya, basuh dengan air, dan mengeringkan tangan. Manfaat melakukan cuci tangan 7 langkah yaitu membersihkan dan membunuh kuman yang 
menempel secara cepat dan efektif karena semua bagian tangan akan dicuci menggunakan sabun (Andriansyah, 2013).

Selain langkah-langkah tersebut, hal lain yang juga kritis dalam pencegahan penyakit adalah waktu kapan seseorang harus mencuci tangan. Menurut Depkes RI (2009), lima waktu terpenting untuk cuci tangan pakai sabun yaitu sebelum makan, sebelum menyusui bayi atau menyuapi bayi/anak, sesudah ke WC atau buang air besar. sesudah menceboki bayi/anak, dan sebelum memasak atau menyiapkan makanan. Namun dikarenakan pandemi Covid-19 maka dianjurkan agar sering- sering mencuci tangan pakai sabun untuk menghentikan penularan virus Covid-19. Menurut SNI, standar sabun cair yang ideal yaitu memiliki bentuk cair, bau, dan warna yang khas (SNI, 1996). Oleh karena itu pembuatan sabun cuci tangan dengan tahapan dan takaran yang benar akan menghasilkan sabun cair yang berkualitas.

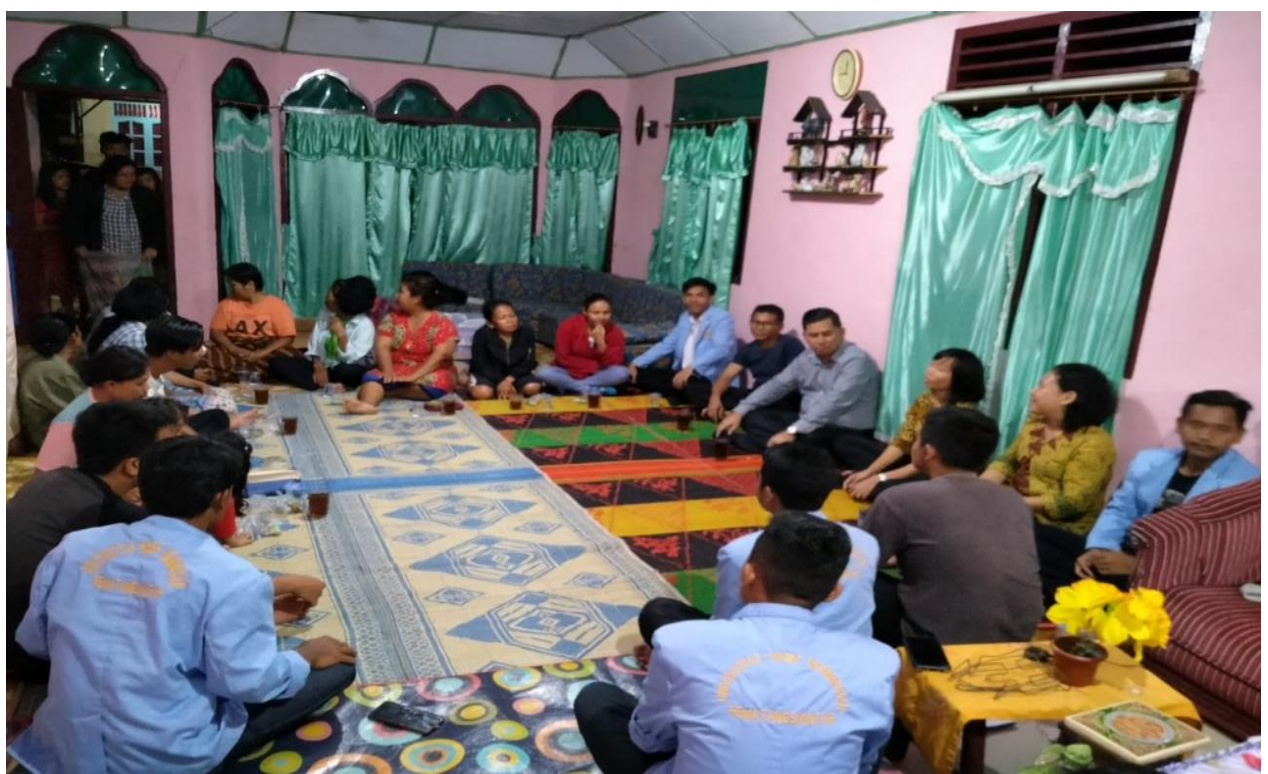

Gambar 1. Tim pengabdi sedang memberikan penyuluhan tentang pentingnya mencuci tangan untuk mencegah penularan virus covid-19

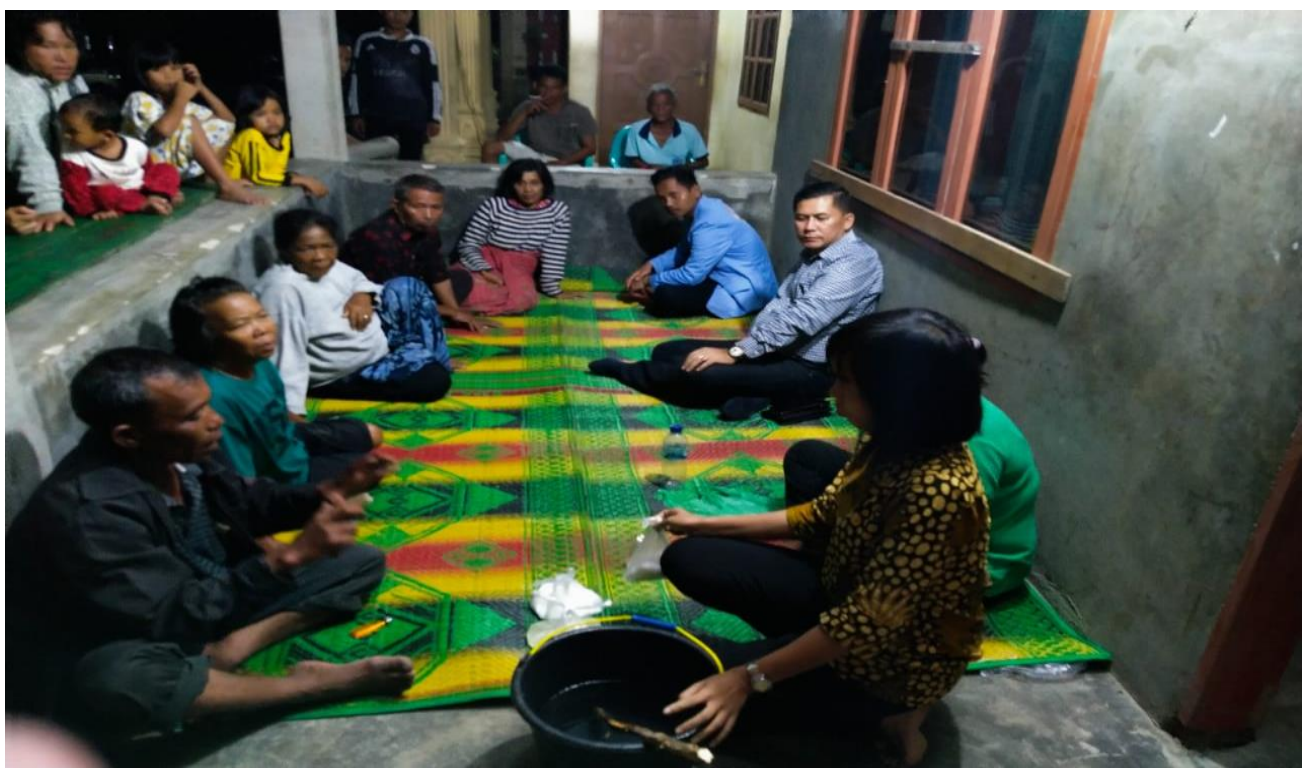

Gambar 2. Tim pengabdi sedang melakukan pelatihan pembuatan sabun cair 


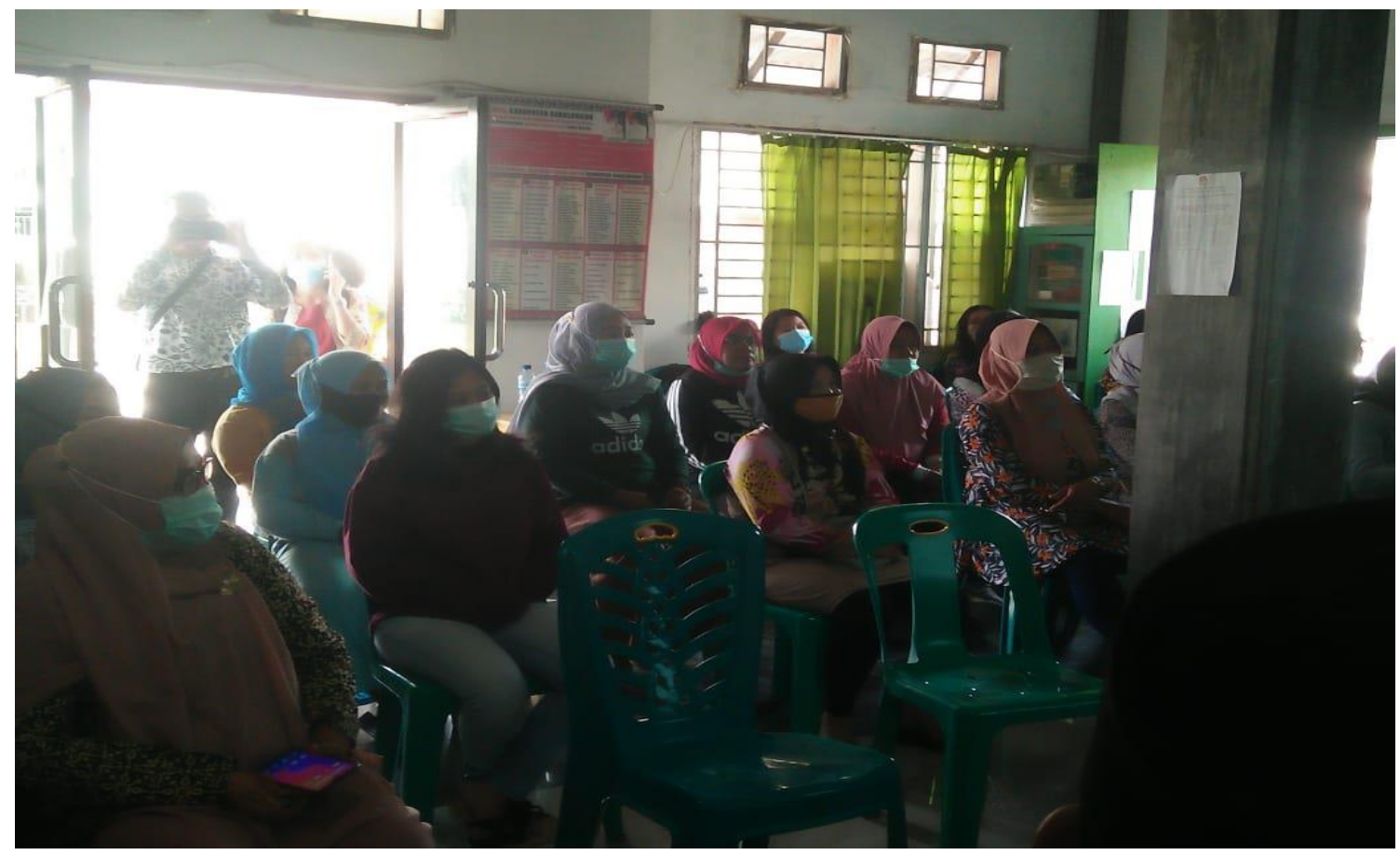

Gambar 3. Peserta pengabdian masyarakat sedang mendengarkan penyuluhan tentang pembuatan sabun cair

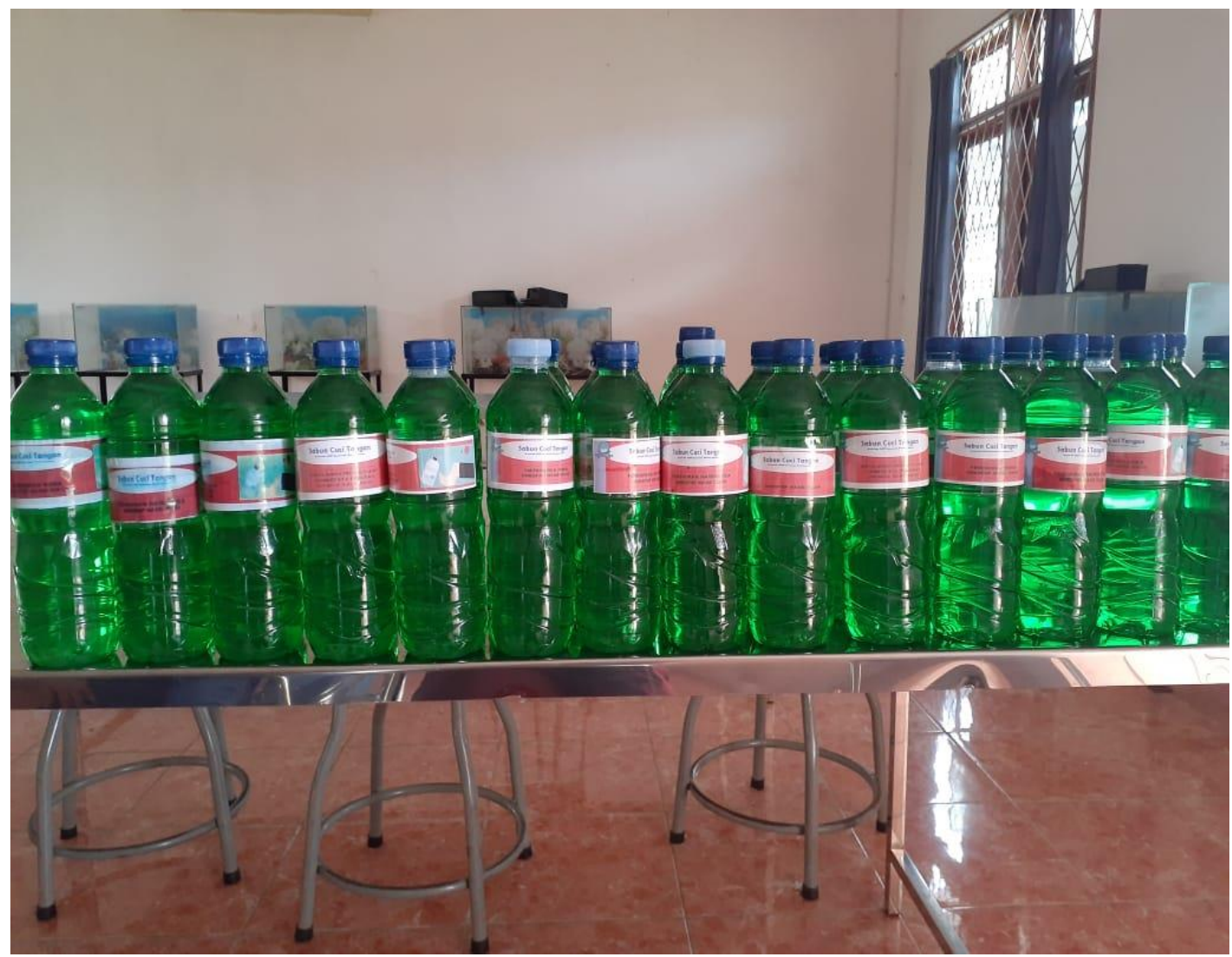

Gambar 4. Produk hasil pelatihan pembuatan sabun cair

Berdasarkan hasil tingkat kepuasan masyarakat, maka diperoleh bahwa masyarakat sangat puas dengan kegiatan PKM yang telah dilaksanakan. . Hal ini dapat dilihat melalui angket kepuasan yang dibagikan oleh tim pengabdi kepada masyarakat yang mengikuti PkM dengan hasil sebagai berikut : 
Apriani Sijabat, Osco P. Sijabat

Mitra Mahajana: Jurnal Pengabdian Masyarakat 2(1), 2021, 15-22

Tabel 1. Tingkat Kepuasan Kegiatan PkM Pelatihan Pembuatan Sabun Cair

\begin{tabular}{llccc}
\hline No & Aspek yang dinilai & Jumlah & $\mathbf{9}$ & Keterangan \\
\hline $\mathbf{1}$ & Kesesuaian dalam memberikan penyuluhan & 17 & 85 & Sangat puas \\
$\mathbf{2}$ & $\begin{array}{l}\text { Ketepatan penggunaan waktu penyulahan dan } \\
\text { pelatihan }\end{array}$ & 14 & 70 & Puas \\
$\mathbf{3}$ & Penyampaian pelatihan pembuatan sabun cair & 15 & 75 & Puas \\
$\mathbf{4}$ & Pemahaman masyarakat dengan pelatihan & 15 & 75 & Mudah Dipahami \\
$\mathbf{5}$ & Pemahaman masyarakat dengan pelatihan & 18 & 90 & Sangat Puas \\
\hline
\end{tabular}

Dari tabel diatas menunjukkan bahwa kesesuaian tim pengabdi dalam memberikan penyuluhan pelatihan sebanyak 17 orang menyatakan sangat puas dan 3 orang menyatakan puas sehingga sebesar $85 \%$ dari jumlah peserta merasa sangat puas. Dalam hal penyampaian pelatihan pembuatan sabun cair sebanyak 15 orang peserta menyatakan puas dan kesesuaian penggunaan waktu juga sebanyak 16 orang peserta menyatkan puas. Untuk aspek kebermanfaatan program masyarakat Tiga balata diperoleh $90 \%$ masyarakat Tiga balata sangat puas dan untuk tingkat pemahaman masyarakat dengan pelatihan yang diberikan tim pengabdi 75\% peserta menyatakan mudah untuk dipahami. Hal ini menunjukkan bahwa penggunaaan metode sosialisasi dan pelatihan memberikan nilai optimal dalam peningkatan pengetahuan dan keterampilan masyarakat.

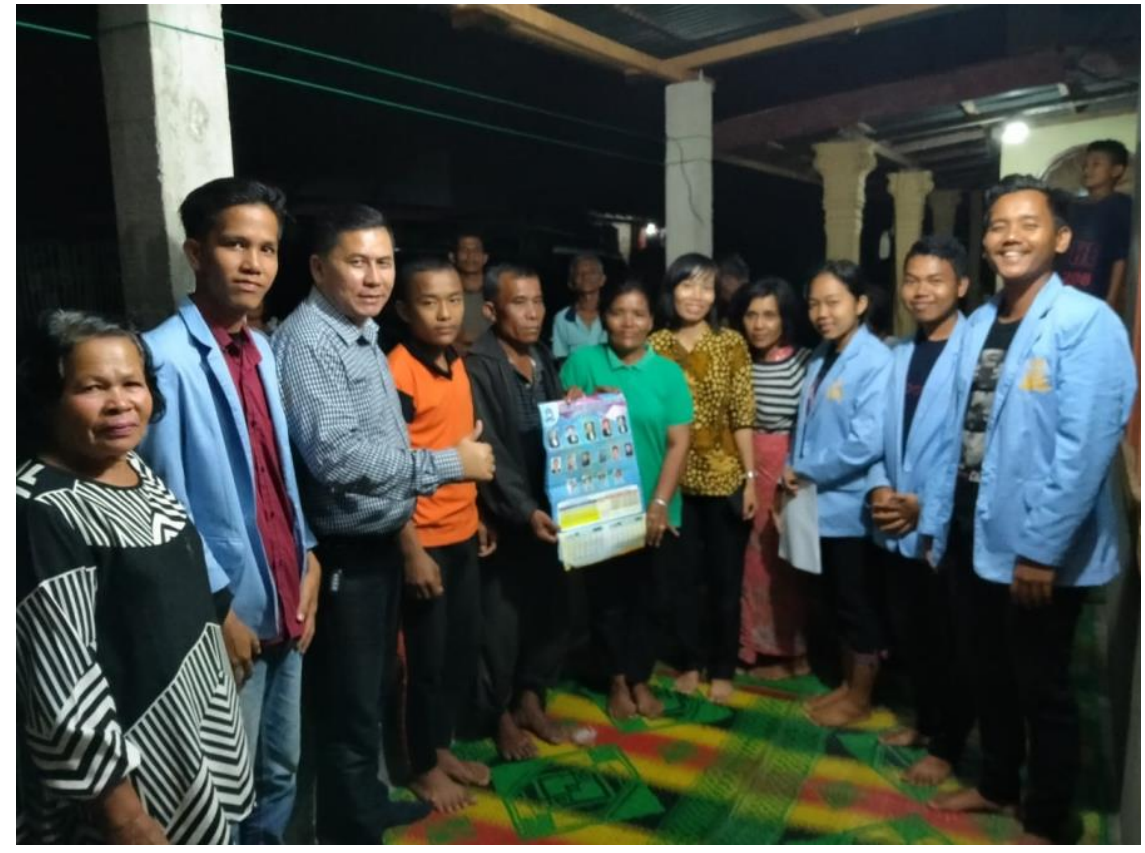

Gambar 5. Foto bersama masyarakat setelah melakukan pelatihan pembuatan sabun cair

Keberhasilan pelaksanaan pengabdian masyarakat yang dilakukan tim pengabdi dapat dilihat dari ketercapaian target peserta dimana jumlah peserta yang hadir sebanyak 26 peserta dari jumlah target sebanyak 30 peserta( $86,7 \%$ ). Sikap antusias terhadap penyampaian materi pada sosialisasi dan tahap pelatihan terlihat jelas ditunjukan masyarakat selama kegiatan PKM. Pengamatan langsung dan wawancara dengan masyarakat menunjukkan hasil bahwa 
masyarakat kelurahan tiga Balata telah berkontribusi melakukan sosialisasi hidup sehat dengan rajin mencuci tangan dengan sabun sebagai upaya pencegahan Covid-19 baik dari diri sendiri, keluarga dan masyarakat.

Pengabdian masyarakat ini juga didukung oleh pemerintah setempat melalui Bapak Lurah di kelurahan Tiga balata. Diakhir kegiatan Lurah Tiga balata yaitu bapak Pondang Sidabutar, SH berpesan semoga semakin banyak pengabdian masyarakat yang dilakukan oleh para dosen yang bermanfaat langsung kepada masyarakat.

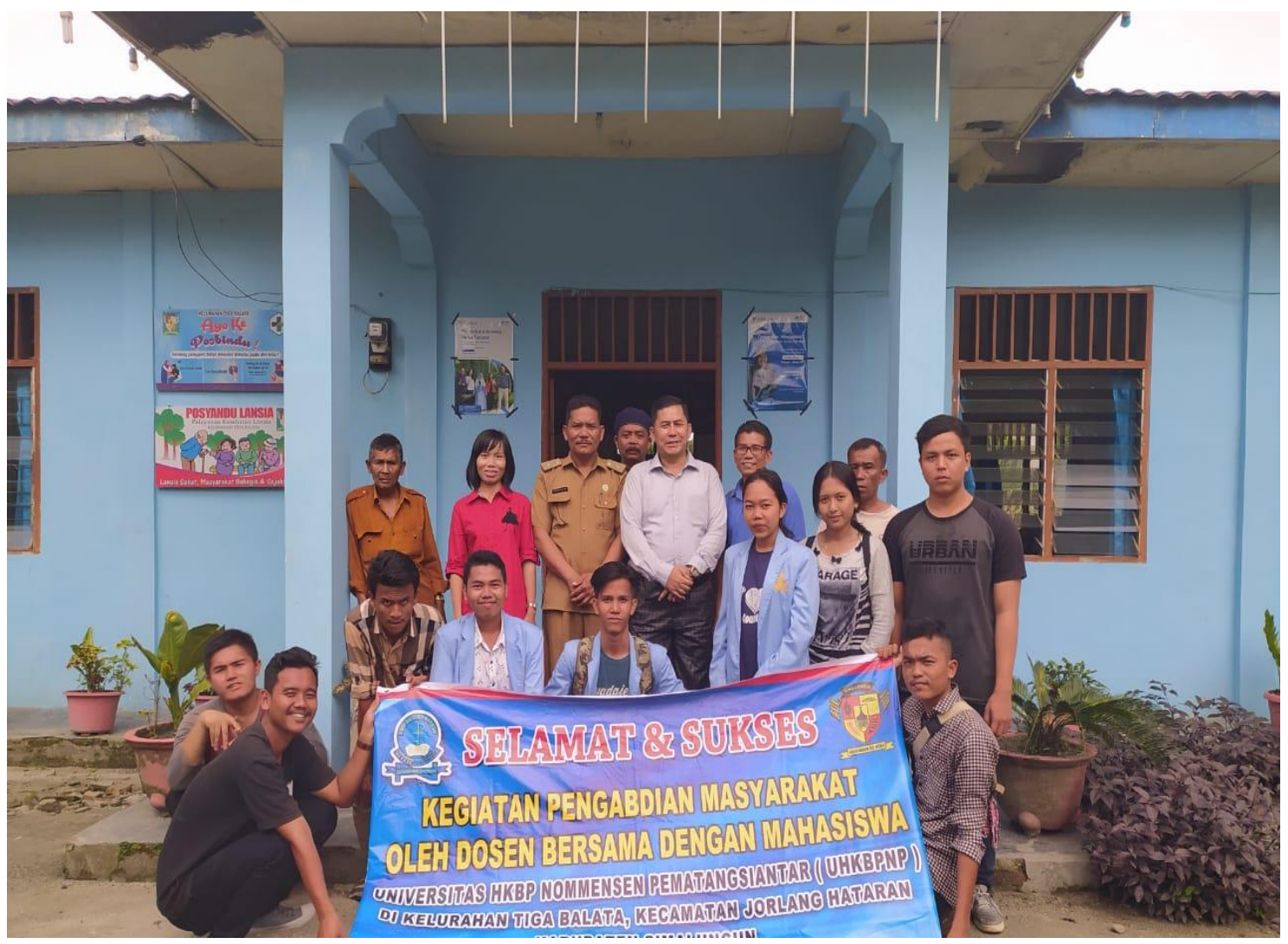

Gambar 6. Foto bersama bapak Lurah Tiga balata dengan tim pengabdi

\section{SIMPULAN DAN TINDAK LANJUT}

Setelah melakukan pengabdian masyarakat ini penulis mengemukakan kesimpulan bahwa kegiatan ini dapat meningkatkan pengetahuan dan ketrampilan dalam pembuatan sabun cuci tangan yang dapat digunakan pribadi maupun dikomersilkan serta dapat memutus mata rantai penyebaran virus covid-19.Diharapkan kedepannya masyarakat dapat meningkatkan keterampilannya dalam mebuat sabun cair sehingga dapat dijadikan sebagai peluang usaha di tengah pandemi covid-19.

\section{DAFTAR PUSTAKA}

Andriansyah, Y., Rahmantari, DN .2013. Penyuluhan dan praktik PHBS (perilaku hidup bersih sehat) dalam mewujudkan masyarakat desa peduli sehat. Seri Pengabdian Masyarakat 2013 ISSN: 2089-3086. Jurnal Inovasi dan Kewirausahaan. 2 (1), p 45-50.

Curtis, V \& Cairncross, S.. (2003). Effect of Washing Hands with Soap on Diarrhoea Risk in the Community: A Systematic Review. The Lancet infectious diseases 2003, 3 (5), 275-281 
Departemen Kesehatan RI. (2009). Panduan Penyelenggaraan Cuci Tangan Pakai Sabun Sedunia (HCTPS). Jakarta

Depkes.2017.Cuci Tangan Pakai Sabun Cegah Kematian Anak. http://www.depkes.go.id/article/view/17101600001/cuci-tangan-pakai-sabuncegah-kematiananak.html.(Diakses 2 Desember 2020).

Kemendikbud. 2020. Surat Edaran Nomor 4 Tahun 2020 tentang Pelaksanaan Kebijakan Pendidikan dalam Masa Darurat Penyebaran Covid-19.

SNI. (1996). Standar Mutu Sabun Cair Cair. Jakarta: Dewan Standarisasi Nasional

WHO. (2009). Guidelines on Hand Hygiene in Healthcare. Geneva: WHO.

World Economic Forum, Palli Thordarson profesor di School of Chemistry di University of New South Wales. https://www.halodoc.com/artikel/cegah-corona-dengan-cuci-tanganperlukah-pakai-sabun-khusus.(Diakses 2 Desember 2020) 